\title{
Inquiry-Learning-Based Module: Improving students' critical thinking skills in Anatomy Structure and Bacteria Physiology materials
}

\author{
Y. Yuhana a,1, ${ }^{,}$M. Maridi b,2, Sri Dwiastuti b,3 \\ a Master of Science Education, Faculty of Education, Sebelas Maret University, Jl. Ir Sutami No. 36A, Surakarta, Central Java, 57126, Indonesia \\ b Science Education study program, Faculty of Education, Sebelas Maret University, Jl. Ir Sutami No. 36A, Surakarta, Central Java, 57126, Indonesia \\ 1yuhana12@gmail.com,,2 maridi_uns@yahoo.co.id, ${ }^{3}$ dwiastuti54@gmail.com \\ "Corresponding author
}

ARTICLE INFO
Article history
Received January 20, 2020
Revised June 25, 2020
Accepted June 30,2020
Published July 15, 2020
Keywords
Anatomy structure
Bacteria physiology
Critical thinking skills
Inquiry-learning-based module

\section{ABSTRACT}

A proper learning media is critically needed in improving students' critical thinking skill. This research and development aims were: 1) determining the characteristics of inquirylearning-based module; 2) observing the feasibility of inquiry-learning-based module prototype, and 3) figuring out the effectiveness of the inquiry-learning-based module developed in improving students' critical thinking on Anatomy Structure and Bacteria Physiology materials. This research and development used 4-D model. The data analysis technique used were descriptive statistics in term of percentage and inferential statistics i.e. paired samples t-test. The results showed that the module developed was very decent based on the averge scores given by all expert validators (90.73\%) as well as education practitioners $(91.99 \%)$. Moreover, students critical thinking skills was improved by using this module as the t-test analysis results (sig. <.05). Thus, the is suggested to implement inquiry-learning based module to achieve better students' learning achievement, particularly in Anatomy Structure and Bacteria Physiology materials.

How to cite: Yuhana, Y., Maridi, M., \& Dwiastuti, S. (2019). Inquiry-Learning-Based Module: Improving students' critical thinking skills in Anatomy Structure and Bacteria Physiology materials. JPBI (Jurnal Pendidikan Biologi Indonesia), 6(2), 341346. doi: https://doi.org/10.22219/jpbi.v6i2.11026

\section{INTRODUCTION}

Rapid development of science and technology in the $21^{\text {st }}$ century brings changes in everyday life (Benesova \& Tupa, 2017). This condition requires educators to provide learning activities which are able to stimulate students' critical thinking skills (Indria et al., 2019) as it is necessary to generate ideas as well as reveal new discoveries in dealing with complex issues arise (T. F. Wijayanti et al., 2016). Furthernore, the skills are a part of higher-order thinking that needs to be empowered in current educational system as the challenges have been more diverse and complex.

Hence, various efforts have been initiated to facilitate learners to conduct a series of scientific activities which address the development of science literacy (Zaidah et al., 2018). By conducting the activities, students are experiencing to apply their knowledge in tackling the problems faced (Ningsih et al., 2018). Likewise, by possessing critical thinking skills, the students are also learning to get use to with their questions related to social issues they face in their daily lives (Halim \& Mokhtar, 2015). As the consequences, the skills ease them to explain scientific concepts, solve problems, and explore causal relationships of the events occurred 
surround them (Irwan et al., 2019). Critical thinking skills are also part of cognitive skills which cover interpretation, analysis, inference, evaluation, explanation, and self-regulation (Wade \& See, 2014).

The students who mastering this skills tend to be more confident and behave based on their logic and systematic reasons they inferred from the information received. In the other words, critical thinking skill is essential to be owned by $21^{\text {st-century generation. }}$

Acknowledging the crucial role of critical thinking skills, scientists have conducted several researches to find out the methods to improve the skills. Some of them proposed learning model (Husamah et al., 2018; Wenning, 2011), module (Setyoko et al., 2017) which was designed to fulfil the inquiry syntax (Facione, 2011) to achieve better students' critical thinking (Elisanti, E, Sajidan, Prayitno, 2018), instrument (M. D. Wijayanti et al., 2019) to measure students' critical thinking, and so forth. However, low critical thinking skills are still orccured in some places, especially Indonesia.

To be more detail, low critical thinking skills were experienced by ten graders of Science Students of State Senior High School (SMAN) 1 Sembalun, East Lombok. The issue was clearly shown in their previous learning achievement in several aspects i.e. interpretation (20.26\%), analysis (30.44\%), inference $(40.41 \%)$, evaluation (34.47\%), explanation (25.10\%), and self-regulation (24.36\%) (unpublished data). Furthermore, students' cognitive level was low. It only reached C3 level of Bloom's Taxonomy as they did their daily test. This also means that their Higher-order Thinking Skills were low (Widoretno \& Dwiastuti, 2019). This low thinking skills were proven as the National Examination scores were revealed. In 2015, the average scores reached by SMAN 1 Sembalun were under Minimum Completeness Criteria in terms of school level (42.32\%), regency level $(50.36 \%)$, province level $(40.21 \%)$ and national level $(59.42 \%)$ (Pusat Penilaian Pendidikan, 2015).

Based on the evaluation done by researcher's team, it was found that the teaching and learning process in classrooms used a textbook as an instructional media. Yet, the implementation of this textbook in the classrooms showed several weaknesses: 1) it contained only materials and exercises; 2) the language used was too difficult to understand by students; 3 ) the implementation done was not in inquiry learning syntax, thus, it could not elevate students' systematic thinking skills. By using the textbook, students' were not guided to think independently in discovering concepts of the materials learnt but receiving teachers' explanation. As the result of this teacher-centered and non-contextual learning, the education quality was low (Bustami et al., 2018).

This study focused on improving students' critical thinking skills by developing inquiry learning-based module which will contribute to the enrichment of learning media, generate effective biology learning, as considerable as initiate the next reserachers to dig deeper fact about learning and conducting their efforts to make learning media better and better. Hence, the purposes of this study were: 1) determining the characteristics of inquiry-learning-based module; 2) observing the feasibility of inquiry-learning-based module prototype, and 3) figuring out the effectiveness of the inquiry-learning-based module developedin improving students' critical thinking on Anatomy Structure and Bacteria Physiology materials.

\section{METHOD}

The inquiry-learning based module was developed based on the 4-D model (Thiagarajan et al., 1974) which covered four stages i.e. defining, designing, developing, and disseminating. The module contained of anatomy structure and physiology of bacteria. The modul produced was assessed by four experts including material, media, language, and learning tool experts. The responses of experts were calculated and being the considerations to revise the modul as well as categorize the modul. The modul quality classification was determined based on the scores obtained and its alignment with module qualification assessment table (Tabel 1).

Table 1. Qualification of module assessment

\begin{tabular}{cc}
\hline Score & Category \\
\hline$>80-100$ & Very decent \\
$>60-80$ & Worthy \\
$>40-60$ & Quite decent \\
$>20-40$ & Not feasible \\
$0-20$ & Not Very \\
\hline
\end{tabular}

The instrument used in this research were ten essays which measured the aspects of critical thinking skills: 1) interpretation, 2) analysis, 3) inference, 4) evaluation, 5) explanation, and 6) self-regulation (Saprudin 
et al., 2019). Moreover, students' pretest and posttest were also employed to determine the improvement of students achievement.

The data gained in terms of retest and posttest were then undergoing normality test as well as paired samples t-test. Furthermore, students' scores were categorized based on students' critical thinking skills criteria (Table 2).

Table 2. Score category of students critical thinking skills

\begin{tabular}{cc}
\hline Score & Category \\
\hline 0.70 & High \\
$0.30-0.70$ & Moderat \\
$<0.30$ & Low \\
\hline
\end{tabular}

\section{RESULTS AND DISCUSSION}

Students' critical thinking skills can be enacted as the proper learning method as well learning as media are employed. Thus, learning media which accommodate inquiry learning to culture students' critical thinking skills is essential, especially for biology students. The learning media developed in this research was underwent experts validation in which the results are served in Table 3.

Table 3. The module assessment results by experts

\begin{tabular}{lcc}
\hline \multicolumn{1}{c}{ Validators } & Score percentage (\%) & Criteria \\
\hline Material Expert & 98.1 & Very decent \\
Media Expert & 82.5 & Very decent \\
Language Expert & 96.5 & Very decent \\
Learning Tool Expert & 85.8 & Very decent \\
\hline Average & 90.73 & Very decent \\
\hline
\end{tabular}

Table 3 shows that based on the results of the experts (material, media, language, and learning tool) validation, the module developed was feasible to use. It can be seen that the average score gained was $90.73 \%$ which means that the module reached "very decent" criteria. In more detail, the highest score obtained was the material (98.1\%) which was followed by language $(96.5 \%)$, learning tool $(85.8 \%)$, and media (82.5).

Table 4. The recapitulation of assessment results by the validators of education practitioner and colleague

\begin{tabular}{lcccc}
\hline \multicolumn{1}{c}{ Validators } & Score I & Score II & Average & Note \\
\hline Education Practitioner & 90.63 & 92.36 & 91.49 & Very decent \\
Colleague & 91.67 & 93.29 & 92.48 & Very decent \\
\hline Average (\%) & & & 91.99 & Very decent \\
\hline
\end{tabular}

Not only was the developed modul assessed by experts, but it also was assessed by education practioner and collegue. The responses are served in Table 4. Based on the results, it is obviousely showed that the module developed was very decent as the scores given by the both education practitioner and colleague reached 91.36 and 92.48 respectively.

A ten question essay test (Facione, 2011) was given to students to measure their critical thinking skills. The data summary of the data obtaine can be seen in Table 5. Based on Table 5, it is known that the students' posttest ( $M=80.86$; S.D.=6.96) was higher compared to their pretest ( $M=61.47 ; S . D .=7.92)$. Moreover, the minimum score achieved in pretest was 25 point lower (45) compared to their posttest lowest score (70). Similarly in the maximum score in which the posttest (92.50) gained 20 points higher than the pretest (72.50).

Table 5. Data description on critical thinking skills

\begin{tabular}{cccccc}
\hline Test & Number of Students & Mean & Std. Deviation & Minimum & Maximum \\
\hline Pretest & 29 & 61.47 & 7.92 & 45 & 72.50 \\
posttest & 29 & 80.86 & 6.96 & 70 & 92.50 \\
\hline
\end{tabular}

As the mean posttest score was higher than the pretest, the elaboration of students' critical thinking skills need to be observed. Table 6 serves the summary data of students' critical thinking skills in more detail 
aspects. The data was taken after the implementation of inquiry-learning-based biology module for anatomy structure and bacteria physiology.

Table 6. Data description on the students' critical thinking skills in every aspect

\begin{tabular}{|c|c|c|c|c|c|c|}
\hline \multirow{2}{*}{ Test } & \multicolumn{6}{|c|}{ Critical thinking skills } \\
\hline & Interpretation & Analysis & Inference & Evaluation & Explanation & Self-Regulation \\
\hline $\begin{array}{l}\text { Average score of } \\
\text { posttest }\end{array}$ & $76.5 \%$ & $64.1 \%$ & $65.2 \%$ & $69.7 \%$ & $79.5 \%$ & $78.8 \%$ \\
\hline
\end{tabular}

Based on Table 6, it is clear that, generally, as refered to the score gained, the aspects were devided into two big groups. The first group contained of those in which the scores reached above $70 \%$. The aspects included in this group were interpretation (76.5\%), self-regulation $(78.8 \%)$, and explanation $(79.5 \%)$. Meanwhile, the second group comprised of the aspects reached the score under $70 \%$ i.e. analysis $(64.1 \%)$, inference $(65.2 \%)$, and evaluation (69.7\%). Yet, the highest score gained by students for explanation and the lowest was analysis aspect.

Notwithstanding that there was an improvement occurred based on the mean score gained, yet it is necessary to ensure its significance. Thus, paired samples t-test as well as its prerequisite condition test in term of normality data were conducted and the results are served in Table 7 . Table 7 implies that the data gained from pretest and posttest were normaly distributed $(p>.05)$. Hence, paired samples t-test was done to ensure the significance different between students' pretest and posttest scores. The test results depicted that the improvement achieved by the students who experienced using the developed module was significant $(p<$ $.05)$.

Table 7. Analysis Results of Normality and Paired Samples t-test

\begin{tabular}{llll}
\hline No & \multicolumn{1}{c}{ Types } & Test & Result \\
\hline 1. & Normality & Kolmogrov-smirnov test & Sig. 0.600 \\
\hline 2. & Pretest and Posttest & Paired samples t-test & Sig. 0.000 \\
\hline
\end{tabular}

The above facts have proven that the inquiry-learning-based module developed for anatomy structure and bacteria physiology materials has benefited students in term of providing them proper learning media. Moreover, the modul was developed in accordance with the core competence as well as basic competence of Kurikulum 2013 which has been implemented in Indonesia. Besides, the module was designed using the syntax of inquiry learning, namely orientation, problem identification, hypothesis frormulation, data collection, test, and conclusion. To be more detail, in orientation phase, students are conditioned to be ready to carry out learning process. Problem identification phase brings students to find the problem is occurring. After identifying the problem, students are guided to generate hypothesis, a possible answer of the problem they has found. The next step done by students is data collection. In this step, students conduct several activities to attain needed information to prove the hypothesis proposed. Test is done as the necessary data were obtained. This step is aimed to analyze the data gained, thus, the hypothesis proposed can be determined if it is accepted or not. The last step is conclusion in which the students are led to infer the finding(s) of their activities done in previous steps.

The module developed has several characteristics which make the module is different compared to the others. One of the characteristics is the design. The inquiry learning aspects were packaged in learning objectives as considerable as were implemented in materials, activities, and evaluations. Furthermore, the ectivities listed in the module contained of inquiry learning syntax starting from orientation, problem identification, hypotheses formulation, data collection, test, and conclusion. In addition, the inquiry-learningbased module was integrated with critical thinking skill aspecs, namely, interpretation, analysis, inference, evaluation, explanation, and self-regulation.

The feasibility of the inquiry-learning-based module to improve the critical thinking skills of ten graders was assessed in two stages. First stage was expert validation test. This stage covered four aspects i.e. material/content, language/readability, media, and learning tool. The second stage was limited field testing. In this stage, the assessment was done by education practitioners including teacher and small number of students. Based on the results of expert validation, the created module is feasible to use.

By considering the results of the both test mentioned, it can be inferred that the module developed is effective to be used as a teaching material in the learning process. There was also significant improvement 
achieved in students' critical thinking skills as the result of the implementation of inquiry-learning-based module. These facts are in line with the research of Zaini and Jumirah (2016) which reported that a good learning media integrated with inquiry learning has contributed to the improvement of students' critical thinking skills, social skills, and work together. Similarly, several researches have implemented inquiry based learning to elevate students' critical thinking skills (Fahrurrizal et al., 2019; Thaiposri \& Wannapiroon, 2015), either in basic or in combining forms such as combined with science-technology-society (Jariyah, 2017) and virtual laboratory media (Wahyuni \& Atun, 2019).

\section{CONCLUSION}

Based on the developing steps of 4-D model conducted by researchers as well as the tests to ensure the effectivity of the module implementation, it can be concluded that the inquiry-learning-based module developed is feasible to use. Furthermore, the module has been proven can significantly improve students' critical thinking skills in science class of $\mathrm{X}$ grade. Thus, it is recommended for teacher to use this module.

\section{REFERENCES}

Benesova, A., \& Tupa, J. (2017). Requirements for education and qualification of people in industry. 27th International Conference on Flexible Automation and Intelligent Manufacturing, 11(June), 2195-2202. doi: https://doi.org/10.1016/j.promfg.2017.07.366

Bustami, Y., Syafruddin, D., \& Afriani, R. (2018). The implementation of contextual learning to enhance biology students' critical thinking skills. Jurnal Pendidikan IPA Indonesia, 7(4), 451-457. doi: https://doi. org/10.15294/jpii.v7i4.11721

Elisanti, E., Sajidan, \& Prayitno, B. A. (2018). The effectiveness of inquiry lesson-based immunity system module to empower the students' critical thinking skill. EDUSAINS, 10(1), 97-112. doi: https://doi.org/ 10.15408/es.v10i1.7259

Facione, P. a. (2011). Critical Thinking: What It Is and Why It Counts. Retrieved from: https://www.student. uwa.edu.au/_data/assets/pdf_file/0003/1922502/Critical-Thinking-What-it-is-and-why-it-counts.pdf

Fahrurrizal, M., Suwono, H., \& Susilo, H. (2019). Studi Komparatif Strategi Pembelajaran Inkuiri Ditinjau dari Kemampuan Kognitif Siswa SMA. JPTPP, 4(6), 747-752. Retrieved from: http://journal.um.ac.id/index. php/jptpp/article/view/12497/5799

Halim, L., \& Mokhtar, L. E. (2015). Critical thinking process in science learning. Prosiding Seminar Nasional Pendidikan Sains V, November, 1-4. Retrieved from: https://www.researchgate.net/publication/304013 631_Critical_Thinking_Process_in_Science_Learning

Husamah, H., Fatmawati, D., \& Setyawan, D. (2018). OIDDE learning model: Improving higher order thinking skills of biology teacher candidates. International Journal of Instruction, 11(2). doi: https://doi.org/10. 12973/iji.2018.11217a

Indria, P. T., Hindun, I., Rofi'ah, N. L., \& Azizah, A. S. N. (2019). Critical thinking skills: Its correlation with academic ability, mastering concepts, and analytical skill of undergraduate students in botany class. JPBI (Jurnal Pendidikan Biologi Indonesia), 5(1), 1-8. doi: https://doi.org/10.22219/jpbi.v5i1.7626

Irwan, I., Maridi, M., \& Dwiastuti, S. (2019). Developing guided inquiry-based ecosystem module to improve students' critical thinking skills. JPBI (Jurnal Pendidikan Biologi Indonesia), 5(1), 51-60. doi: https:// doi.org/10.22219/jpbi.v5i1.7287

Jariyah, I. A. (2017). The effect of Inquiry Combined Science-Technology-Society (STS) learning to enhance critical thinking skills on science. JPBI (Jurnal Pendidikan Biologi Indonesia), 3(1), 1. doi: https:// doi.org/10.22219/jpbi.v3i1.3888

Ningsih, P. R., Hidayat, A., \& Kusairi, S. (2018). Penerapan Problem Based Learning untuk Meningkatkan Kemampuan Berpikir Kritis dan Hasil Belajar Siswa Kelas III. Jurnal Pendidikan, 3(12), 1587-1593. doi: https://doi.org/10.17977/jptpp.v3i12.11799

Pusat Penilaian Pendidikan. (2015). Laporan Hasil Ujian Nasional Tahun Pelajaran 2014/2015. Puslitbang Kemendikbud.Retrieved from: https://pusmenjar.kemdikbud.go.id/hasilun/

Saprudin, S., Liliasari, S., Prihatmanto, A. S., \& Setiawan, A. (2019). Pre-service physics teachers' thinking styles and its relationship with critical thinking skills on learning interference and diffraction. Journal of Physics: Conference Series, 1157(3). doi: https://doi.org/10.1088/1742-6596/1157/3/032029

Setyoko, S., Rohman, F., \& Suwono, H. (2017). Development of Animals Ecology Module for macrozoobentos 
community at higher institution. JPBI (Jurnal Pendidikan Biologi Indonesia, 3(1), 80. doi: https://doi.org/ 10. 22219/jpbi.v3i1.3908

Thaiposri, P., \& Wannapiroon, P. (2015). Enhancing students' critical thinking skills through teaching and learning by inquiry-based learning activities using social network and cloud computing. Procedia - Social and Behavioral Sciences, 174, 2137-2144. doi: https://doi.org/10.1016/j.sbspro.2015.02.013

Thiagarajan, S., Semmel, D. S., \& Semmel, M. I. (1974). Instructional development for training teachers of exceptional children: a sourcebook. ERIC. doi: https://files.eric.ed.gov/fulltext/ED090725.pdf

Verawati, N. N. S. P., Prayogi, S., Gummah, S., Muliadi, A., \& Yusup, M. Y. (2019). The effect of conflictcognitive strategy in inquiry learning towards pre-service teachers ' critical thinking ability. Jurnal Pendidikan IPA Indonesia, 8(4), 529-537. doi: https://doi.org/10.15294/jpii.v8i4.21002

Wade, W. P., \& See, Y. H. M. (2014). Measuring critical thinking as learning outcome: A pilot study from the ideas and exposition module. Asian Journal of the Scholarship of Teaching and Learning, 4(4), 220236. Retrieved from: http://nus.edu.sg/cdt//docs/default-source/engagement-docs/publications/ajsot//arc hive-of-past-issues/year-2014/v4n4_december2014/pdf_vol4n4_wpwade-yhmsee.pdf?sfvrsn=7a1574e d_2

Wahyuni, T. R., \& Atun, S. (2019). Pengembangan media laboratorium virtual berbasis inkuiri materi larutan elektrolit dan non-elektrolit. JPTPP, 4(5), 674-686. Retrieved from: http://journal.um.ac.id/index. php/jptpp/article/view/12472/5777

Wenning, C. J. (2011). The levels of inquiry model of science teaching. JPTO, 6(2), 9-16. Retrieved from: http://www2. phy.ilstu.edu/ cjwennin/jpteo/issues/jpteo6(2)sum11a.pdf

Widoretno, S., \& Dwiastuti, S. (2019). Improving students' thinking skill based on class interaction in discovery instructional: A case of lesson study. Jurnal Pendidikan IPA Indonesia, 8(3), 347-353. doi: https:/l doi.org/10.15294/jpii.v8i3.20003

Wijayanti, M. D., Rahardjo, S. B., Saputro, S., \& S. Mulyani. (2019). Item analysis of critical thinking skills instrument to measure effectiveness of Scientific Group Inquiry Learning (SGIL) Model. Jurnal Pendidikan IPA Indonesia, 8(4), 538-546. doi: https://doi.org/10.15294/jpii.v8i4.20794

Wijayanti, T. F., Prayitno, B. A., \& Sunarto, S. (2016). Argument mapping pada materi Sistem Pernapasan untuk meningkatkan kemampuan berpikir kritis siswa kelas XI SMA Negeri 5. INKUIRI: Jurnal Pendidikan IPA, Februari 2016, 105-111. doi: https://doi.org/10.20961/inkuiri.v5i1.9516

Zaidah, A., Sukarmin, \& Sunarno, W. (2018). The effect of physics-based scientific learning on the improvement of the student's critical thinking skills. J. Phys.: Conf. Ser, $1006012023,1-5$. doi: https:// doi.org/10.1088/1742-6596/1006/1/012023

Zaini, H. M., \& Jumirah, R. (2016). Pengembangan perangkat pembelajaran topik Ekologi terhadap keterampilan berpikir kritis siswa Madrasah Aliyah. JPBI (Jurnal Pendidikan Biologi Indonesia), 2(1), 39-47. doi: https://doi.org/10.22219/jpbi.v2i1.3370 